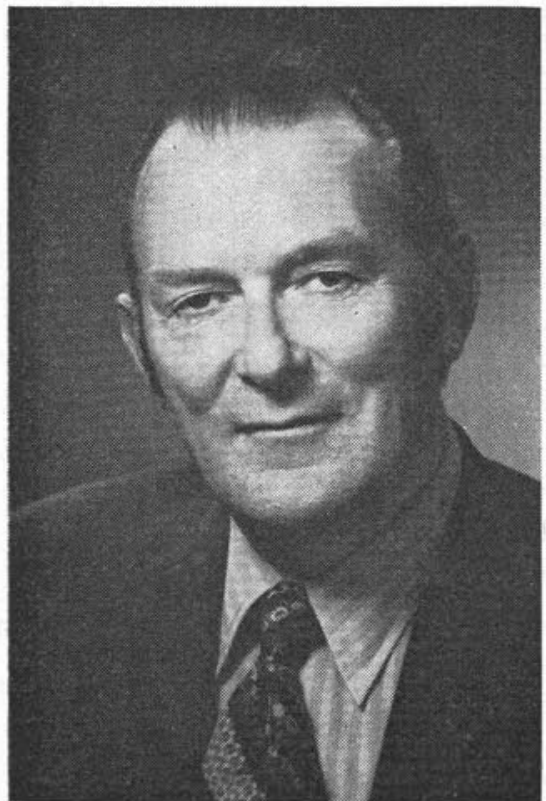

A. B. Anderson President

\section{President's Report}

In the June issue of The Forestry Chronicle I reported extensively on your Executive Committee's February meeting with the Honourable Roméo LeBlanc, Minister of Fisheries and the Environment. In the course of reporting I bemoaned the fact that we had received no written response to our letter of February 2 and reached the point where we expected none. Well, the Minister has put the lie to me: I have since received, on your behalf, an encouraging letter specifically in response to ours of February 2. It is reproduced below and is followed by excerpts from the Minister's statement before the Standing Committee on Fisheries and Forestry to which he has referred in his letter.

Text of Letter from Mr. Roméo LeBlanc, Minister of Fisheries and the Environment which was dated June 20th, 1977

\section{Dear Mr. Anderson:}

Please accept my apologies for not answering sooner the letter of February 2, 1977, that you tabled when your Executive Committee met with me and Dr. R. J. Bourchier, Director General of the Canadian Forestry Service. You will recall that I told you, at that time, that I was then in the process of studying federal responsibilities in forestry. You raised several important points and I didn't want to reply formally until my study was complete. The time has now arrived.
I am enclosing a copy of "Minutes of Proceedings and Evidence of the Standing Committee on Fisheries and Forestry" of Tuesday, April 26, 1977. This contains my statement supporting the program of the CFS for the fiscal year $1977 / 78$. You will find in it answers to some of the questions you raised. For instance, on Page 6,1 have touched on six important subjects of concern to the federal government; on the following two pages, I discussed six forestry problems in Canada; and on Page 8, I identified six functions for the CFS.

I recall that we discussed for some time on February 2, the question of the need of a forest policy for Canada. I trust that you will find acceptable my comments on this subject, beginning on Page 8. The recent CCREM meeting in Saskatoon encourages me to think we can evolve a policy.

I specifically recall our discussion on your proposals (Paragraph No. 14), for providing incentives for investment in forestry through taxation. This was of such interest to me that I have requested officers in my Department to prepare a background paper, outlining proposals on how this may be implemented.

I found the meeting with your Executive Committee thought-provoking and helpful and I repeat the wish I expressed then, that we meet again in a year or so and review progress in federal forestry programs.

Yours sincerely, Roméo LeBlanc

Excerpts from the Minutes of Proceedings and Evidence of the Standing Committee on Fisheries and Forestry which were specifically referred to by the Minister in his foregoing letter.

From the Minister's Statement

Federal concerns and interests. The provinces own most of Canada's productive forest land. Notwithstanding pre-eminent provincial jurisdiction, federal concerns and interest that bear on the wise use of Canada's forest resources include:

1) employment levels and regional disparities;

2) management of the economy and regulation of trade and commerce;

3) management of federal forest and wildlands;

4) provision of national statistics;

5) maintenance of Canada's technological and scientific base, and

6) conservation of energy and non-renewable resources.

The Canadian Forestry Service. A number of agencies are responsible for federal input into forestry. The most important, however, is the Canadian Forestry Service (CFS) within the Department of Fisheries and Environment. This organization has the expertise, based on its scientific and technical program, to advise the federal government on many forestry and related matters. 
During the fiscal year 1977-78, the Canadian Forestry Service has 1,407 man-years and a budget of $\$ 34.3$ million. The $1976-77$ figures showed 1,442 man-years and $\$ 36,563,000$ and $1975-76,1,471$ manyears and $\$ 34,200,000$. In 1972-73, the service had 1,693 man-years and a budget of $\$ 32,219,000$. It operates four National Research Institutes, forest products laboratories in Ottawa and Vancouver, and regional research centres at St. John's, Fredericton, Quebec City, Sault Ste. Marie, Edmonton, and Victoria.

The Canadian Forestry Service objective is to promote the wise management and use of Canada's forest resources and wildlands for the economic and social benefit of all Canadians.

By wise management, we mean management for the multiple and integrated use of forest land. Thus the CFS must promote greater efficiency and lower costs in forestry and wood processing operations while also promoting the maintenance of the long-term productivity and environmental quality of the forests for less tangible benefits such as recreation.

Forestry problems and opportunities in Canada. We have given much thought recently to the forestry situation in Canada and have identified six major problems and opportunities facing this country in connection with her forest resources. These are as follows:

1) Deteriorating competitive position of the industry. This is owing to a variety of reasons including inflation, labour and logging costs, poorer quality of the remote forests now being logged, costs of pollution control and failure to modernize many plants.

2) Shortfalls in forest replacement. About 70 million acres, $12 \%$ of Canada's productive forest land, are now inadequately stocked with trees and we are adding 500,000 acres to this backlog annually.

3) Impact of economic development. Economic developments of many sorts are pre-empting or damaging thousands of square miles of forest land. Forestry practices such as mechanized logging, use of fire and pesticides can have some detrimental effect.

4) Conservation of nonrenewable resources. Wood is a renewable resource with great potential for replacing nonrenewable resources, both as a material and potential source of energy.

5) Economic and environmental impact of forest fires and pests. Over two million acres of forests have been burned over annually for the past ten years. Insects and other pests kill or damage an enormous amount of timber each year.

6) National statistics on the forest estate. Canada does not have adequate national statistics for demand, supply, depletion, rate of growth or allowable cut of our forests. Nor does she have national statistics on the non-consumption and recreational demands on our forests.

Future role of the Canadian Forestry Service. In our current review we have identified six functions to enable the CFS to respond to the challenges just outlined.

1) Provide the national focus for forestry matters and co-ordinate federal activities and policies relating to forestry;

2) Mount a technical program addressed to major problems and opportunities related to the forest resource;

3) Promote an effective federal role in improving standards of management and utilization of Canada's forest resources;

4) Produce and disseminate national forest resource statistics;

5) Contribute strongly to departmental environmental objectives;

6) Co-ordinate forestry and related research by other performers across Canada and co-ordinate Canada's intervention in international forestry matters.

Specific program items. The programs of the Canadian Forestry Service cannot be covered in detail but I shall spend a few moments on some specific items that may interest the Committee, namely national forest policy, spruce budworm, forest industry pollution, and conservation of energy and nonrenewable resources.

1. National Forest Policy. Canada does not have a national forest policy nor eleven consistent provincial and federal policies that take into account the diverse interests involved. Within the federal government many agencies have policies and activities that affect forest resource use or development.

Canada does not have a national focus for ongoing policy analysis and development to ensure that provincial and federal actions and policies affecting the use and management of the forest resource are consistent and in accord with the long-term needs.

As a result of this department's initiatives, the matter of a national forest policy will be discussed at the annual meeting of the Canadian Council of Resource and Environment Ministers at Saskatoon on June 1st. However, this is just the beginning of the long-term effort needed to provide consistent policy analysis and advice on a national basis. This is why I am suggesting establishment of a federal interdepartmental committee on forestry.

Energy and Conservation of renewable resources.

Wood is a renewable resource. If we use the forests to the limit of their potential capacity, we can reduce our dependence on nonrenewable resources as well as provide and conserve energy. Major increases in forest production are possible through reforestation and silviculture treatments. Tree breeding can increase the productivity of some species by 15 to $25 \%$.

Major savings are possible by more efficient processing, and more efficient use of wood in structures. The environmental and energy costs of wood as a construction material are vastly lower than those of steel, aluminum or concrete and its use will conserve energy. 
Wood itself can be used to produce energy; it can be burned directly to produce steam for generating electricity; it can be converted to gas. It can be converted to methanol which would allow its use as an extender of gasoline for transport use. The possibility of methanol production is under serious study. A pre-feasibility study has been completed and the report can be made available to Committee members who would like to have it. Wood and other tree tissues can be used as a source of chemicals or converted into animal fodder. This latter use would release much high quality agricultural land for producing crops for direct human consumption.

The Canadian Forestry Service has conducted much research on growing forests for conventional uses; e.g. lumber, pulp and paper. They plan some shifts in this research program to develop forest management techniques for producing maximum yields of wood suitable for the new uses mentioned above.

\section{From the Minister's Answers to Questions put to him by the Members of the Committee}

Mr. Chairman, when I said I felt we needed a national forestry policy, I also think we need a national government forestry policy. In other words, I feel and I have felt this very strongly, that within the Government of Canada we have departments which can affect the forests and work together. I am thinking of Transport and IT and C, obviously the environmental side of the department, and those others, Finance for discussion of tax matters, etc. I have initiated this effort to get the people in the Government of Canada dealing with forestry matters or affecting forestry matters to meet and to work together...

Mr. Chairman, I do not know whether any new general agreements have been negotiated with the provinces since I became minister. There is no doubt that at one time projects were presented by the provinces and approved with a minimum of consultation, because it was their responsibility to make proposals to the federal Department of Regional Economic Expansion.

There has been a change in attitude in this sector. We are more frequently consulted by other departments and fully intend to assume our responsibility. Since we have set up work and research institutes, perhaps the most sophisticated in the country, I think that it is normal to want to put some effort into co-ordination and to avoid duplication in the provincial and federal sectors.

At present, we are at the complete disposal of other departments, especially the Department of Regional Economic Expansion and I intend to continue in this vein because I think that it is important that the Canadian Forestry Service become the advisory body or consultant to the federal government in all matters related to forests.

I think that a national policy is possible with the active co-operation of the provinces, the identification of the roles that can be played by the two levels of government, provincial and federal, and the continued efforts to avoid useless quarrelling by looking at the problems which arise, the questions that must be resolved. Unfortunately, the spruce budworm does not pose too many constitutional problems, it eats everything in its path and does not recognize international or provincial borders.

This is why it is important for the Ministers of Natural Resources, when they meet at the end of May, to tell us whether they are ready to work with us. As I said, we now have people available to us who are interested in forest matters, impressive and specialized scientific services which could be very useful to us. What I would like to see is more co-ordination and directed effort...

There is one essential role that the Canadian Forestry Service can play and it is not played very much by most foresters: the role of substantial research and the level of competence which it has and which is recognized, which I get in letters and which I am sure other members of this Committee have got. And it is recognized as a very precious part of our national wealth of knowledge, if I can use that expression. For that reason, I have decided that I would give this some attention, that I would encourage the officials in this service to refocus their thinking, refocus their priorities and to come up with rearrangements.

I hope that down the road, in fact by focusing better on this matter with other departments it will be able to convince them that we should be looking at more long-term programs. I have to say that in a field which is not of our jurisdiction, the expenditure of $\$ 34$ or $\$ 35$ million is not a mean sum - is not a small sum. But I still think if the Canadian Forestry Service did not exist we would have to invent it because of the level of excellence it has obtained and the role that it is playing in many provinces where really minimal research is being done.

\section{Text of Reply to the Minister's Letter of June 20, 1977}

Dear Mr. LeBlanc:

We were very pleased to receive your letter of June 20th in response to ours of February 2nd, which was discussed with you in Ottawa that same day. Because of the long delay we had assumed that no formal reply would be forthcoming and accordingly we reported on that basis to our membership in the June issue of The Forestry Chronicle. Now we will be able to report further on our meeting with the publication of your letter in the August issue, along with excerpts from your statement and answers to questions made on April 26th before the Standing Committee on Fisheries and Forestry. So that you may acquire a measure of our reaction I have enclosed a photocony of my June report to the membership of the CIF as it appeared in The Forestry Chronicle and a carbon copy of the report I have just prepared for the August issue.

I must tell you that we all have been heartened by what we have read in the minutes of the Standing Committee. We believe that you and your staff 
are on the right path, and we pray that you will not be diverted by the play of political forces as so frequently happens in government.

One matter we brought before you in February involved that of CIF representation on the Canadian Forestry Advisory Council. You received this request for representation favourably, agreeing that it was worthy of serious consideration, and that off-hand, you could think of no practical reason for refusing this request. We would like to have your final decision on this as we consider that our professional representation on the Council could be of value to you and to forest management in Canada.

Referring to your recent letter we have been encouraged by your note on a background paper covering incentives for investment in intensified forest management practices through taxation. As we promised you last February we have set our Economics Working Group to studying the same matter for the purpose of presenting a paper to you when we hold our next Executive Committee meeting in Ottawa this coming January or February. We trust you again will favour us with an audience.

Meanwhile we hope you will accept our invitation to present a policy paper, along with $\mathrm{Mr}$. Adam Zimmerman of Northwood Pulp and Timber
(Noranda) at the Canadian Institute of Forestry annual meeting on October 3 in Vancouver. It would be an honour for the Institute and would provide a platform and a fine opportunity to state the position of your government on matters vital to Canada's forests and its people. We believe strong leadership in this area is essential and will produce significant results.

In concluding, Mr. Minister, I want to thank you on behalf of the Executive Committee, and indeed on behalf of the whole Institute for your courtesy in receiving us last February and giving so freely of your time.

Yours truly,

\section{A. Brookman Anderson, R.P.F. President}

I don't think there is much I want to say, after all this. I shall leave it to you to form your own opinions. However, your Executive Committee is encouraged. We appear to have in our Minister an intelligent, capable and understanding man who recognizes the limitations placed by government on the actions he and his Canadian Forestry Service might take; who is rapidly developing an understanding of the problems facing Canada's forests; and who appears to be determined to do the best he can to resolve those problems within the constraints that bind him.

\section{Management and Utilization of Hardwoods}

As Chairman of the Silviculture Working Group of the $\mathrm{CIE}$ it has been my pleasant duty to correspond with the nine authors of articles about hardwoods, and with the editor. Pleasant, because of the tremendous enthusiasm of these forestry people for their work, and their willingness to take time to share it with you, as you read this issue.

Several provincial government forestry services, and especially Ontario, Quebec, New Brunswick and Nova Scotia are now wrestling with a new forest policy for hardwoods. Quality or quantity? Production, protection, or amenity forestry? Yield predictions? Markets? Transportation?

These questions are being raised and foresters are hard pressed to answer. Needs are many and guidelines are few. In some sort of order these needs are:
Market Opportunities

Improved utilization

A site classification for hardwood and mixedwood cover types

Managed hardwood yield tables

Unevenaged stand yield tables

Hardwood inventory by quality classes

Silvicultural guides for a range of management objectives.

Topics covered in this Chronicle issue range from fuelwood to genetics, and give some indication of current interests. The aesthetics of the hardwood forest are not discussed here, but in parks and other recreation areas and in urban forestry they are very important. The October Chronicle, the editor has advised us, will deal with "many aspects of urban forestry".

J. C. Lees

Chairman

Silviculture Working Group 